tual fraternity that has sustained me throughout my life.

AG \& RH: You were born in 1942. These were hard times for the Albanian population of Kosova. What was your family like? What difficulties did you face while growing up, and what was your life like?

AP: It is true what you just said. The 1940s were the years of Nazi ghosts. Those were years of horror and bloodshed, starvation. Albanian children had no childhood. They were raised in hardship and poverty and the horrors of a dirty, inhumane war. I remember the barbaric behavior of neighboring countries, which would do anything to turn my country into a wasteland without functioning institutions; we had neither hospitals nor schools. However, we relied on the deep support of good people, especially certain American sympathizers to whom we became very close after many Albanian intellectuals who crossed the Atlantic were integrated into a country that breathed freely and stretched its hand toward life; there was something there that restored our trust that there is still something good in this world. We all looked to the United States.

AG \& RH: One of our favorite poems of yours is "When Will You Speak Out, Ali Podrimja," which you wrote in 1990, a pivotal year that witnessed not only the end of Yugoslavia but also the beginning of one of the darkest decades of Kosovar history: beginning with the Yugoslav War and ending with the Kosova War of 1998-99. Yet it had been thirty years since your first volume of poetry had been published. What was it you wanted to speak out about, and have you spoken out about it yet?

AP: Albanians have lived under the difficulties of foreign rule for centuries. We still hear the horrors of Toplica, ${ }^{2}$ where Serbs would grab children from their mothers and throw them in basins of boiling water, from which they would not come out alive, or when children and elders would be thrown into fiery stoves, which would burn them horribly, as though they were potatoes. I recommend you read the book Beteja e Toplices (The Battle of Toplica) and see for yourself how hundreds and thousands of elders, women, and children became cinders and ashes, or read about the horrors of Cameria, ${ }^{3}$ from which Albanians were forcefully expulsed by Greeks with unprecedented violence. Similar things happened in Has: the Serb Dimitrije Tucović himself, but also the elders who saw how the blood flowed as a river, witnessed the terror, burnings, killings, robberies, rapes, and ethnic cleansing of Albanians all over Kosovo. Within six months between October 1912 and March 1913, the Serbs slaughtered over twenty-five thousand people, and the streets of my Gjakova were full of human remains. The war correspondent Leo Freundlich offers firsthand accounts in his book Albania's Golgotha, published in Vienna in 1913. No other nation's fate was gambled with like Albanians'; no other nation's interests were toyed with in the Balkans or Europe as were the Albanians', and it is well known who is to be blamed for that, the author says. The point of all this terror was to divide Albania in pieces so that no sign or trace of it would remain. Why all this hate against a nation of heroes and numerous historical figures? It's inexplicable.

We also experienced many atrocities during the Serbian and Yugoslavian regime of Milošević, of which we were witnesses and against which I raised my voice as a poet in my writings and at international gatherings. Particularly terrible was the "Memorandum of Serbian Academics"4 jointly signed by Serbian writers, Orthodox priests and primates, which called for bloodshed against Albanians, calls that strengthened those of Serbian military and paramilitary commanders. This was madness. These were times of a life-and-death struggle against the Serbian neofascists and neochetniks who had us against the wall. And I did not remain silent.

Muses do not remain silent just because bombs and helicopters are "talking." Poets never remain silent during wars and great social revolutions, during great crimes and injustices, during the struggle against the fascism and communism of the previous century. Even in discursive writings, together with a small group of intellectuals, I have raised my voice against socialist-realist literature, which we almost paid for with our lives.

Spiritual feelings, great events, and injustices toward my people made me write poetry. In my creations, when I talk about horrors, I remember my own mother, who witnessed the killing of her

\section{Poets never}

remain silent during

wars and great social revolutions, during great crimes and injustices, during the struggle against the fascism and communism of the previous century.

LEFT On "The Road Less Traveled" in the Sharr Mountains National Park, Brezovicë, Kosova. Photo by Trim Kabashi. 
Adam J. Goldwyn, currently a postdoctoral researcher in Byzantine Greek at Uppsala

University, Sweden, was formerly Assistant Professor of English at the University of New York in Tirana, Albania, and Lecturer in English at the American University in Kosovo.

Rineta Hoxha, a Pristina native, currently studies at the American University in Kosovo. seven brothers at our front door by the Serbs. It was unbelievable how far the brutality of humans can go. How could they kill children and elders? How could they massacre pregnant women? How could they rape young girls?

In 1960, during the Yugoslavian Communist regime, I wrote the poem "Kosova is my blood; no apologies." Because of this courageous act, I almost ended up in prison, as did many other Albanians, but I was lucky to be saved by the writer Esad Mekuli, to whom I will always be grateful. Instead, I was suspended from the Gjakova gymnasium and thus left to "hang out" in the streets without knowing where to go. Those who suspended me from the school belonged to the secret Communist police, who worked against the well-being of Kosova and peace among men. This verse became the motto or loyalty oath of the UÇK [the Ushtria Çlirimtare e Kosovës, known in English as the Kosova Liberation Army or KLA] and young Albanians, an anthem and flag for the young freedom lovers in the war against Milošević's regime. This great honor filled my eyes with tears. This was a sign of great respect but also a sign that it is worth writing and getting involved in contemporary social streams.

It is the role of the poet never to remain silent toward injustices that are done to nations or individuals. Robert Frost, the American poet, put the cause of homeland among the most important causes. Today, we have independence, which some see as a shirt covered with blood hanging from the branches of an oak. George Orwell talks about the commitment of the real creator. That existence, identity, and peace are born from the contours of that mystery called politics. A resolution, an ethnic issue, for instance, can be born from a message. If the Albanian state does not have similar politicians, that does not mean that its spiritual creators do not hold their homeland and nation emotionally close to their souls. A part of those emotions, from the Renaissance and earlier, got melted into verses for these major issues. Frost did his best to remind the "extraterrestrials" what the homeland is and to whom it belongs.

Unfortunately, it happens that sometimes a homeland is seen as a thing dropped along the road, a black hole. Some people value trivial things more than a homeland. What I love and what connects me to the United States is freedom, democ- racy, and human understanding. From my earliest poetry, I had the United States, which I could read as the story of humanity prevailing against evil, as a guide. I even identified American English as the language of writers' freedom.

AG \& RH: Moving to Albanian literature more generally, the noted Albanologist Robert Elsie, who translated not only your collection of poems in English, Who Will Slay the Wolf, but also many other works of Albanian literature, writes that you are "considered by many to be the most typical representative of modern Albanian verse." What are the defining features of modern Albanian verse? How does your poetry fit into the longer tradition of Albanian poetry, and how have younger poets adapted your work?

AP: Almost every day for a long time after my parents died, I used to go to the cemetery to visit them. My parents taught me what humanity means and how to respect that. The education they gave me, combined with some American and global books I read secretly from the Serbian secret police, encouraged me. Everything human and educational forms tradition and should not be forgotten. This is the tradition that lives in my contemporary verses. I do not know how historians, critics, and scholars of literature consider or classify my work, but that does not matter. What matters is that my poetry is understood and admired by readers. Whether I am traditional or contemporary is not really relevant. I was never interested in literature schools, the "-isms." They change all the time. The great works done with great human spirit, however, such as those of Homer, Shakespeare, and others, those endure forever. I would not define Albanian contemporary verse or its influence on new poets. Each has its merit, its own creative style. Time is the best classifier of values.

AG \& RH: We all feel love, but artists have a unique opportunity to express it. Because of Albanians' political status throughout history, many of your best poems are on this subject. What place does this divine feeling have in your writing? Who and what inspires you in your love poems?

AP: You are right. Love is something divine. It brings joy in life. The greatest poets have dedi- 
cated some of their best verses to the beauty and love of women. It is crucial to recall the human being as the most beautiful creature in nature. First, artists should love each human being as a magnificent creature. I prepared a book for the great Albanian humanist and Nobelist Mother Theresa, titled Teach Me to Love, published in Albanian and English and distributed to all world politicians and humanists at the Vatican during her beatification. I feel a pure love toward her. Women suffered a lot throughout history and without enjoying equal rights with men; there is no progress and no real social life. We posses many folkloric songs about this feeling, and they represent the peak of beauty and love. Such songs are the songs of Shkodër, Gjakova, and, especially, Korça's serenades. I value verses of a sincere, real love, but I am against platonic love of the type "Mood and dust I would become, so her feet steps over me."

Sándor Petőfi, the great Hungarian romantic and patriot, did say that he would give everything for love, but for protection of homeland, he would give even love. He was right. The cause of the homeland is the cause of causes. Living for a long time under occupation, for us, Albanian poets, the primary issue was national liberty, survival, but without forgetting love toward women, who through history stood side by side with men in the fight for freedom and independence.

AG \& RH: This interview will be accompanied by your poetic cycle "The Trojan Horse" from your 1971 volume Torso. Images from Greek mythology have been a recurring theme in Albanian literature. Your poem "Ithaca," from the volume Happy Ending (1988), for example, discusses the powerful symbolism of Odysseus's island. Indeed, your fellow Kosovar Din Mehmeti also wrote a poem about Ithaca and the lost home called "Olympia," as did the Albanian Bardhyl Londo ("Ithaca" and "Only Ithaca Remains"). In his "I Dislike Achilles," Fatos Arapi compares himself and the Albanians to Hector and the Trojans, and the Albanian dictator Enver Hoxha to the Greek warrior Achilles, whose great and destructive power he both hates and fears. ${ }^{5}$ What is the power of mythological metaphors for you or for Albanian and modern poetry generally? Does your poem have similarly allegorical readings?

\section{Three Poems by Ali Podrimja}

\section{And You Never Forgot}

Here and there beyond barred windows

Chasing you people forgot themselves

Here and there beyond barred windows they poisoned your air And you never forgot them

You never forgot them

God is amazed and your air got poisoned by people

Here and there beyond barred windows

\section{After the Thunder, They Erased Your Tracks}

The drums were beaten on top of the world Troy trembles They were played to insanity and you don't hear them They were played day and night while you dream the frosty years You dream of another quake to shake the world

People stuck in an anonymous time

Write their history in blood and suffering

Your tracks were erased after the thunder

The drums are played with no rest and you flee from the light

\section{Go Back to Homer's Verse}

Go back to Homer's verse

Go back from whence you came

This is not your time go back

Free the people from themselves

And free shadows from disguises

And free escapes from sleeplessness

And free silence from fever

And rains this is not your time

Go back to Homer's verse

Troy has fallen and long it's been

Since the people have sung the Marseillaise

Translations from the Albanian

By Adam J. Goldwyn and Rineta Hoxha 
From my

earliest

poetry, I had the United

States, which

I could read

as the story

of humanity

prevailing

against evil, as

a guide.
AP: There is no real literature without the use of these images. Literature, particularly poetry, without metaphors, symbols, myths, and irony is not literature. Without these figures there is no modern literature. Without myth and symbolism, not only from ancient Greece but also Illyria, wars of liberation, destroying demons, sacrifice for the nation, society, friends, and human well-being, there is no real poetry. Whether it be Din Mehmeti, Bardhyl Londo, or Fatos Arapi, whom I consider real poets, many writers have used poetic figures to escape communism, writing about the past but alluding to those regimes that, along with Stalinism, were a plague on humanity. Frankly, there is no strong poetry without metaphors, symbols, myths, and other poetic figures. Certainly, this is the poet's strongest weapon. How my poetry is read by others, I cannot know, but that they like my work, that is clear to me.

AG \& RH: You are going on a trip in a few days to visit different countries. What is the purpose of this trip and how will your presence there open a way to a better recognition of your writings and Albanian literature?

AP: The traveling of artists could be considered a bridge between nations and people. Through some writers, Albanian literature had created its own good image in the world, in particular through the novels of Ismail Kadare, Fatos Kongoli, and others. My mission is to represent my art, my people, and my literature, which in none of the historical periods appeared to be chauvinist, but tolerant and benevolent for the progress of any other peaceful nation in the world.

AG \& RH: Your hometown of Gjakova has a long tradition of being on the receiving end of a uniquely Albanian brand of dark humor. What's your favorite Gjakovar joke?

AP: "May your mind grow up."6

AG \& RH: What question do you wish we had asked that we didn't?

AP: You have asked plenty of questions! And even within your questions were woven a lot of other questions. "When will you speak, Ali
Podrimja" was a scream addressed to the hungry and terrified people suffering under Serbian terror. This terror, which aimed to swallow the whole Albanian space and every living thing in it, seemed impossible to defeat. Therefore, this scream of mine was the scream of the people who did their best to awaken a sleeping world, while my poem "Who Will Slay the Wolf?" was a kind of announcement that we were going to be freed from the wildness of the black blood.

February 2012

${ }^{1}$ Kosovo declared independence on February 17, 2008. Though not universally acknowledged, the International Court of Justice, at the behest of the United Nations, deemed this declaration legal in a nonbinding advisory ruling on July 22, 2010.

${ }^{2}$ A region in Sanxhak of Niš (Albanian), also called Sandžak (Serbo-Croatian). This is the border region between modern-day Montenegro, Serbia, and Kosovo. It was part of the Ottoman Empire until the Treaty of San Stefano, which ended the Russo-Turkish War (1878). The transfer of land from the defeated Ottomans to the victorious Serbo-Russian alliance created the modern Serbian state and resulted in the cleansing of the local Albanian population to which Podrimja refers.

${ }^{3}$ The Albanian term for the Epirus region of northern Greece and southern Albania, from which many Albanians were expelled; many others remain citizens of Greece as ethnic minorities.

4 "The Memorandum of the Serbian Academy of Arts and Sciences," better known as the SANU Memorandum, published in 1986, which argued for stronger action to reverse what the authors perceived as the oppression of ethnic Serbs within the Croatian and Kosovar majority regions of Yugoslavia. The aggressive nationalism in this document was both a reflection and instigator of the tensions that led to the Yugoslav Wars.

${ }^{5}$ Hoxha's Communist rule (1941 until his death in 1985) was particularly harsh, even by the standards of Eastern European Communists, on dissidents and artists. See Adam J. Goldwyn, "Exile and Nostalgia in Albanian Lyric Poetry Since 1750," Mediterranean Journal of the Humanities 1:1 (2011), 123-41.

6 “Hajt bacë t'u rrittë mendja": not so much a joke as a proverbial Gjakovar expression directed at those too selfobsessed or arrogant to realize how little they truly know. 